\title{
ANALISIS PERBANDINGAN VARIASI 3 FILTER PADA REKONSTRUKSI CITRA PEMERIKSAAN CT SCAN MASTOID
}

\author{
Novianty Sutrisno ${ }^{1)}$, Pramudya Ade Kusumaputra ${ }^{2)}$, Guntur Winarno ${ }^{3)}$, Shinta Gunawati ${ }^{4)}$ \\ ${ }^{1,2,3,4}$ Poltekkes Kemenkes Jakarta II, Indonesia \\ Corresponding author: Novianty Sutrisno, Pramudya Ade Kusumaputra \\ e-mail: novianty0807@gmail.com, pram.amr@gmail.com
}

\begin{abstract}
Background : This study aims to determine the differences in the quality of anatomical image information and to determine the best reconstruction variation of the Mastoid CT scan.

Methods : The design of this study was quantitative and qualitative analysis, conducted in the radiology unit of Banten Hospital with the study population was all patients who underwent a head CT scan. The sample was taken using a purposive sampling technique specifically for the Mastoid CT Scan examination with clinical mastoiditis. Image reconstruction was performed with three variations of the filter, namely bone standard, bone smooth, and bone sharp for analysis.

Result : The results obtained were that there were no significant differences in the SNR values of the three filter variations, but there were differences in the CNR values of the three filter variations.

Conclusion : Based on the study conducted, it can be concluded that data obtained qualitatively according to clinical and the results of interviews with ENT specialists and radiologists that the bone sharp filter gets the highest rate which is used to analyze Mastoid CT images, and it is recommended to assess mastoid CT images with clinical mastoiditis.
\end{abstract}

Keywords: Mastoid CT Scan, Filter

\section{Pendahuluan}

Mastoid merupakan rongga berisi udara yang terdapat pada tulang temporal yang berhubungan dengan nasofaring melalui tuba eustachius dan berhubungan dengan mastoid air cells (rongga mastoid) melalui antrum tympanic (aditus ad antrum). Rongga timpanik dan mastoid merupakan kelanjutan dari saluran pernafasan dan menjadi tempat yang sering mengalami infeksi yang berasal dari saluran pernafasan melalui tuba eustachius (Alper et al., 2017; Juliano et al., 2013; Louis et al., 2009; Petaros et al., 2015; Swarts et al., 2013). Multislice Computed Tomography (MSCT) saat ini merupakan teknik yang paling akurat untuk mempelajari anatomi dan patologi tulang temporal karena dapat memberikan hasil citra tulang - tulang bagian dalam organ telinga dengan sangat baik(Heilbrun et al., 2003; Reiser et al., 2014; Seeram, 2016; Swartz, 2001; "The Essential Physics of the Medical Imaging, 3rd edJerrold T. Bushberg, J. Anthony Seibert, Edwin M. Leidholdt, Jr, and John M. Boone Philadelphia, Pa: Lippincott Williams \& Wilkins, 2012. ISBN: 978-0-7817-8057-5. Hardcover, \$199.99; pp 1048.," 2015).

CT scan mastoid membutuhkan resolusi yang sangat baik. Yang paling utama adalah slice thickness yang tipis, rekonstruksi algoritma high resolution, dan Field Of View (FOV) yang kecil (Romans, 2018; Schaefer- 
Prokop et al., 2001; Seeram, 2016). Salah satu parameter yang mempengaruhi kualitas pencitraan pada CT scan adalah filter atau lebih dikenal dengan kernel yang dapat meningkatkan kontras resolusi, spasial resolusi dan mengurangi noise. Parameter filter yang terdapat pada modalitas imaging MSCT untuk pemeriksaan CT scan mastoid terutama kondisi window tulang yaitu filter standard $(\mathrm{H} 40)$ digunakan untuk hasil citra jaringan lunak di kepala. Filter bone smooth (H20) dan untuk filter bone sharp digunakan (H50) untuk gambaran lebaih tajam. Semakin tinggi nilai filter (H.70s atau H.90s) semakin tinggi penggunaan algoritma rekonstruksi semakin tajam hasil citra (Cheng et al., 2017; Darmini et al., 2020).

Sering dijumpai pemeriksaan CT scan Mastoid tidak menggunakan parameter CT scan Mastoid melainkan menggunakan parameter CT scan kepala. Oleh karena itu, berdasarkan latar belakang tersebut, diperlukan penelitian tentang analisis perbandingan variasi 3 filter pada rekonstruksi citra pemeriksaan CT Scan Mastoid, dengan tujuan untuk menganalisa pengaruh penggunaan filter bone standart, bone smooth dan bone sharp terhadap hasil rekonstruksi citra CT Scan mastoid. Serta untuk menentukan parameter filter yang tepat untuk pemeriksaan CT scan mastoid.

Penggunaan filter atau kernel dalam CT scan sangat penting untuk menghilangkan kebanyakan efek Bluirring, dan sangat melekat dengan rekonstruksi citra CT scan yang menggunakan teknik yang disebut dengan back projection. Semakin tinggi rekonstruksi filter atau kernel yang dipilih maka semakin tinggi resolusi citra yang dihasilkan. Dengan adanya metode ini maka citra seperti tulang, soft tissue dan jaringan jaringan lain dapat dibedakan dengan jelas pada layar monitor. Filter untuk resolusi tinggi yaitu yang mampu memperjelas tepian organ atau perbatasan organ akan menghasilkan citra yang lebih baik, tetapi tingkat noisenya akan lebih tinggi. Filter atau kernel pada CT scan dapat juga didesain untuk meningkatkan kualitas tepi pada citra dan menghasilkan tampilan yang lebih tajam, sehingga dapat meningkatkan kontras resolusi, spatial resolusi dan kemudian mengurangi kehadiran noise.
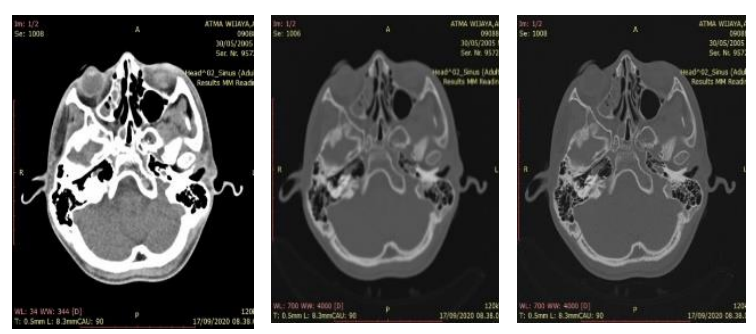

A

B

C

Gambar 1. Hasil rekonstruksi filter standart (A), bone smooth (B), dan bone sharp $(\mathrm{C})$

\section{Metode}

Penelitian ini menggunakan metode analitik kuantitatif, kualitatif dengan menggunakan data Retrospective. Dilakukan pada bulan november - desember 2020. Sampel dipilih dengan pendekatan teknik purposing sampling sebanyak 10 sampel yang melakukan pemeriksaan CT scan mastoid. Pemeriksaan menggunakan modalitas MSCT Siemens Definition AS 64 slices dengan ketebalan rekonstruksi citra $3 \mathrm{~mm}$. RAW data pasien yang telah melakukan pemeriksaan dilakukan rekonstruksi dengan menggunakan filter bone standart (J40), bone smooth (J30S), dan bone sharp (J70). Dari hasil rekonstruksi tersebut dipilih 2 irisan dari masing-masing sampel pada filter yang digunakan. Data DICOM irisan tersebut kemudian di analisa nilai individual pixel, nilai mean dan standar deviasi dengan menggunakan software ImageJ. Software Image $J$ ini mampu untuk menampilkan, menganalisa, memproses, dan menyimpan format DICOM. Software ini menganalisa dengan menggunakan Region of Interst (ROI) (strasdat $\mathrm{H}$ ). Dari pengukuran menggunakan software ImageJ didapatkan nilai Mean HU, Mean min, Mean max, dan standar deviasi dari ROI yang dibuat. Nilai tersebut digunakan untuk menghitung nilai Signal to Noise Ratio (SNR) dan Contrast to Noise Ratio (CNR) dengan menggunakan persamaan berikut : 
SNR $=\frac{\text { Average Mean }(\text { HU) }}{\delta \pi \text { (standar Devias }}$

CNR $=\underline{\text { Mean HU max }-\mathbf{N}}$ Pasien

$\frac{\text { C Backgrouı }}{\delta}$

Nilai SNR dan CNR J kemudian dibandingkan dengar uji statistik Anova dengan software pengolahan data statis

Selain itu juga dilakukan $\mathrm{p}$ kualitatif dengan melakuka kepada responden dari dc radiologi dan dokter spesial: menilai resolusi kontras, re noise dan artefak secara si responden. Hasil penilaian dib: rata-rata yang diperoleh.

\section{Hasil dan Pembahasan}

Dari penghitungan dengan software ImageJ, diperoleh ni Mean min, Mean max, dan standar deviasi dari ROI yang dibuat. Nilai tersebut kemudian diolah dengan menggunakan persamaan SNR dan CNR. Nilai SNR yang diperoleh dari persamaan tersebut ditampilkan pada tabel 1 .

Tabel 1. Nilai Signal to Noise Ratio Pasien SNR (signal to Noise Ratio)

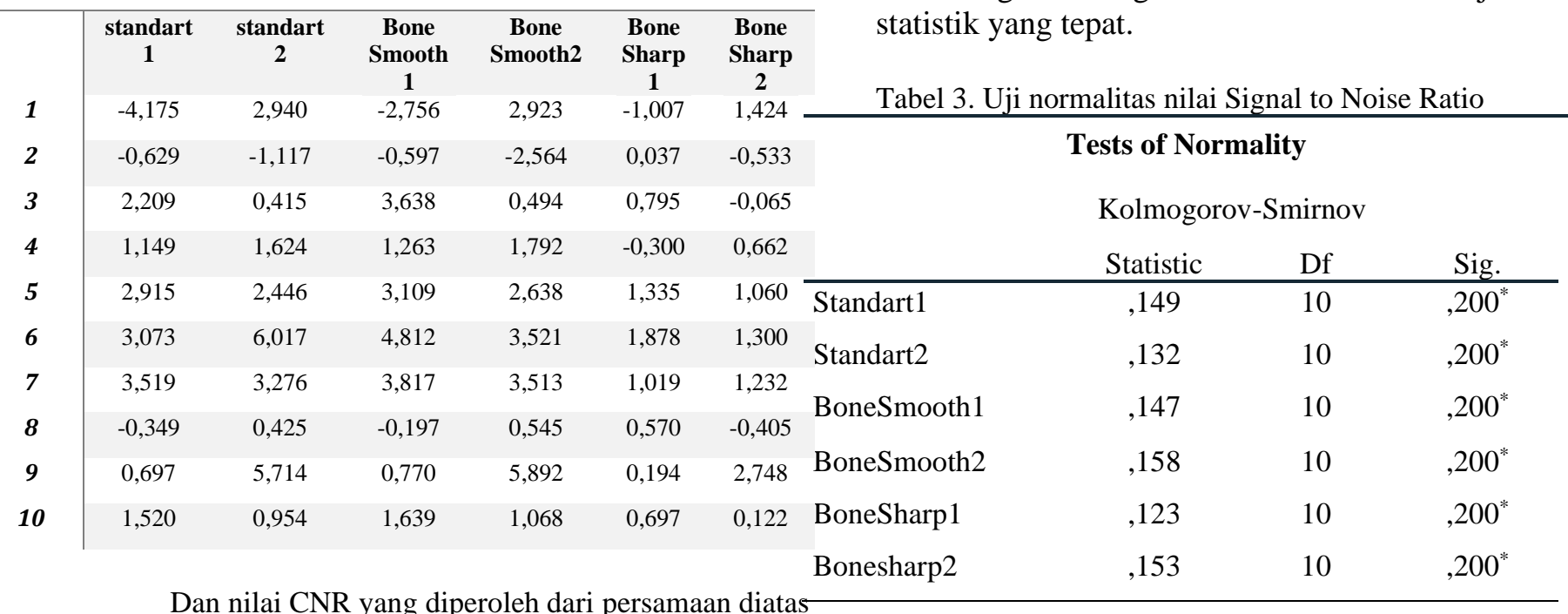

Tabel 2. Nilai Contrast to Noise Ratio CNR (Contrast to Noise Ratio)

\begin{tabular}{|c|c|c|c|c|c|}
\hline 1 & 2 & Smooth 1 & Smooth 2 & $\begin{array}{c}\text { Sharp } \\
1\end{array}$ & $\begin{array}{c}\text { Sharp } \\
2\end{array}$ \\
\hline $\begin{array}{l}1.151,218 \\
\text { peroleh }\end{array}$ & $1.252,792$ & $1.293,606$ & $1.411,643$ & 103,503 & 104,819 \\
\hline 76,153 & 198,790 & 263,213 & 231,090 & 73,301 & 74,690 \\
\hline 200,010 & 722,591 & 214,427 & 840,140 & 96,491 & 91,521 \\
\hline 818,762 & 203,802 & 93,328 & 219,743 & 71,092 & 51,006 \\
\hline petsigapes & 419,926 & 520,535 & 503,494 & 84,224 & 87,239 \\
\hline$\underset{1.814,412}{\text { untuk }}$ & $1.347,854$ & $1.324,340$ & $1.556,069$ & 171,209 & 137,520 \\
\hline $\begin{array}{r}659,446 \\
\text { an nilai }\end{array}$ & 571,724 & 730,067 & 687,521 & 90,956 & 93,311 \\
\hline 917,748 & 235,169 & $1.054,427$ & 244,032 & 168,704 & 97,239 \\
\hline 249,176 & 175,639 & 312,861 & 198,077 & 45,644 & 55,662 \\
\hline$\widehat{8} 96,64 \overline{45}$ & 790,757 & $1.069,467$ & 979,167 & 105,629 & 71,744 \\
\hline
\end{tabular}

Sebelum dilakukan uji statistik, data yang sudah diperoleh sebelumnya harus dilakukan uji normalitas terlebih dahulu. Uji ini dilakukan untuk mengetahui apakah data yang diperoleh memiliki distribusi normal atau tidak. Juga berfungsi untuk menentukan uji statistik yang tepat.

Tabel 3. Uji normalitas nilai Signal to Noise Ratio

ditampilkan pada tabel 2. 
Tabel 4. Uji normalitas nilai Contrast to Noise

\begin{tabular}{lccc}
\multicolumn{4}{c}{ Ratio } \\
& \multicolumn{2}{c}{ Tests of Normality } \\
& $\begin{array}{l}\text { Kolmogorov-Smirnov } \\
\text { Statistic }\end{array}$ & Df & Sig. \\
\hline Standart1 &, 157 & 10 &, $200^{*}$ \\
Standart2 &, 194 & 10 &, $200^{*}$ \\
Smooth1 &, 188 & 10 &, $200^{*}$ \\
Smooth2 &, 210 & 10 &, $200^{*}$ \\
Sharp1 &, 255 & 10 &, 064 \\
Sharp2 &, 134 & 10 &, $200^{*}$ \\
\hline
\end{tabular}

Dari tabel Test of Normality diatas menunjukkan hasil Uji Kolmogorov-Smirnov dari nilai SNR. Pada Standart1, standart 2, bone smooth 1, bone smooth 2, Bone sharp 1, dan bone sharp 2 p value adalah $0,200>$ dari 0,05 , maka sebaran data berdistribusi normal. Dan hasil Uji Kolmogorov-Smirnov nilai CNR. Pada Standart $1 \mathrm{p}$ value $0,200>0,05$, standart $2 \mathrm{p}$ value $0,200>0,05$, bone smooth $1 \mathrm{p}$ value $0,02>0,05$, bone smooth $2 \mathrm{p}$ value $0,200>0,05$, Bone sharp $10,064>0,05$, dan bone sharp $2 \mathrm{p}$ value $0,200>0,05$, maka sebaran seluruh data berdistribusi normal. Maka uji statistik yang digunakan untuk menguji perbedaan data diatas adalah uji Anova.

Setelah diperoleh hasil uji normalitas, data SNR dan CNR dilakukan uji Anova untuk melihat perbedaannya. Masing-masing data diuji sesuai dengan kelompok citra nya. Hasil uji Anova ditunjukkan pada tabel 5 dan 6.

Tabel 5. Uji Anova nilai Signal to Noise Ratio

SNR UJI ANOVA

Nilai Signifikans. SNR Citra Kelompok 1 0,508

SNR Citra Kelompok 2 0,205

Pada uji Anova nilai SNR diperoleh nilai signifikans $\mathrm{p}(\mathrm{p}$-value $)=0,508$ pada citra kelompok 1 dan $\mathrm{p}$ (p-value) $=0,205$ pada citra kelompok 2. Dengan demikian dikarenakan nilai signifikans $0,508>0,05$ dan $0,205>$ 0,05 maka Ho diterima, sehingga diputuskan tidak ada perbedaan yang bermakna rata-rata nilai SNR berdasarkan ketiga kelompok filter pada potongan gambar 1 dan 2 tersebut.
Tabel 6. Uji Anova Contrast to Noise Ratio UJI ANOVA

CNR

\begin{tabular}{lc} 
& $\begin{array}{c}\text { Nilai } \\
\text { Signifikans. }\end{array}$ \\
\hline CNR Citra Kelompok 1 & 0,003 \\
CNR Citra Kelompok 2 & 0,003 \\
\hline
\end{tabular}

Pada uji Anova nilai CNR diperoleh nilai signifikans $\mathrm{p}(\mathrm{p}$-value $)=0,003$ pada citra kelompok 1 dan $\mathrm{p}(\mathrm{p}$-value $)=0,003$ pada citra kelompok 2. Dengan demikian dikarenakan nilai signifikans $0,003>0,05$ dan $0,003>$ 0,05 maka Ho ditolak, sehingga diputuskan ada perbedaan yang bermakna rata-rata nilai CNR berdasarkan ketiga kelompok filter pada potongan gambar 1 dan 2 tersebut.

Hal ini sesuai dengan kepustakaan bahwa semakin tinggi penggunaan algoritma rekonstruksi maka semakin tajam citra yang didapatkan. Perbedaan nilai Contrast to Noise Ratio (CNR) terdapat pada penggunaan filter bone smooth dengan bone sharp pada masing masing kelompok gambar menunjukkan semakin tinggi algoritma filter rekonstruksi yang digunakan, maka citra akan semakin tajam dan memiliki kontras yang tinggi.

Untuk mengetahui dimana perbedaannya maka dilakukan uji statistik selanjutnya yaitu uji Post Hoc Bonferroni. Uji ini juga merupakan bagian dari uji Anova untuk membandingkan nilai mean dari data.

Tabel 7. Uji Bonferroni CNR Kelompok 1

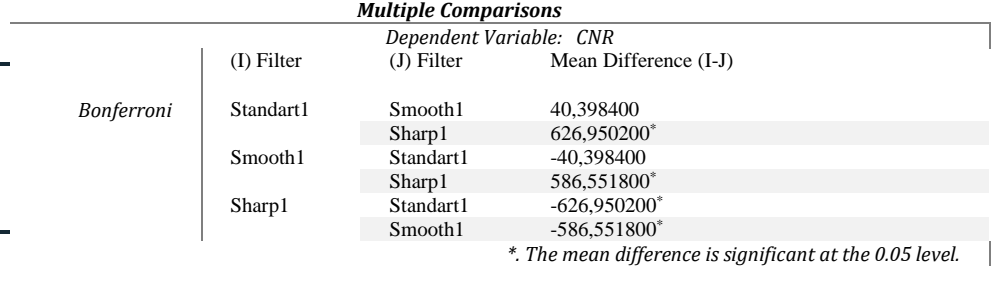

Tabel 8. Uji Bonferroni CNR Kelompok 2 Multiple Comparisons

Dependent Variable: CNR

Mean

Difference (I-

\begin{tabular}{cllr} 
& (I) Filter & (J) Filter & \multicolumn{1}{c}{ J) } \\
\hline Bonferroni & Standart2 & Smooth2 & $-95,193200$ \\
& & Sharp2 & $505,429300^{*}$ \\
& Smooth2 & Standart2 & 95,193200 \\
& & Sharp2 & $600,622500^{*}$ \\
& Sharp2 & Standart2 & $-505,429300^{*}$ \\
& & Smooth2 & $-600,622500^{*}$ \\
*. The mean difference is significant at the 0.05 level. \\
\hline
\end{tabular}


Dari tabel uji Post Hoc diatas dapat dilihat citra pada filter apa saja yang memiliki perbedaan nilai mean CNR. Pada citra kelompok 1 dan 2 terlihat bahwa filter standart dan smooth tidak memiliki perbedaan mean yang signifikan. Perbedaan nilai mean terlihat pada filter sharp dengan standart dan filter sharp dengan smooth pada citra kelompok 1 maupun kelompok 2.

Sebagai pembanding juga dilakukan wawancara terhadap 3 orang responden dari dokter spesialis radiologi untuk menilai citra CT scan mastoid secara kualitatif.

Tabel 9. Hasil rata-rata penilaian kualitatif.

\begin{tabular}{|c|c|c|c|}
\hline \multirow[b]{2}{*}{ Sampel } & \multicolumn{3}{|c|}{ Hasil rata-rata penilaian kualitatif } \\
\hline & $\begin{array}{c}\text { Nilai Rata- } \\
\text { rata } \\
\text { Resolusi } \\
\text { spasial }\end{array}$ & $\begin{array}{c}\text { Nilai Rata- } \\
\text { rata } \\
\text { Resolusi } \\
\text { Kontras }\end{array}$ & $\begin{array}{l}\text { Nilai Rata- } \\
\text { rata Noise }\end{array}$ \\
\hline Filter Satndart & 2,8 & 2,6 & 2,3 \\
\hline Filter Bone Smooth & 1,0 & 1,0 & 1,7 \\
\hline Filter Bone Sharp & 3,7 & 3,9 & 3,3 \\
\hline
\end{tabular}

Hasil yang diperoleh menunjukkan bahwa filter bone sharp mendapatkan penilaian tertinggi sebesar 3,7 untuk resolusi spasial, 3,9 untuk resolusi kontras, dan 3,3 untuk noise. Diurutan kedua adalah filter standart yang mendapatkan penilaian 2,8 untuk resolusi spasial, 2,6 untuk resolusi kontras, dan 2,3 untuk noise. Dan di urutan terakhir adalah filter bone smooth yang mendapatkan penilaian 1 untuk resolusi spasial, 1 untuk resolusi kontras, dan 1,7 untuk noise.

Juga dari hasil wawancara yang telah dilakukan, didapatkan bahwa filter bone sharp merupakan filter yang paling baik untuk menilai klinis mastoiditis. pemeriksaan CT scan mastoid. Hal ini sesuai dengan keinginan dokter klinisi bahwa ketika pemeriksaan CT Scan mastoid dilakukan adalah untuk menilai kelainan pada Cellulae Mastoidea atau Mastoid Air Cell. Hasil penelitian diatas juga sesuai dengan kepustakaan bahwa CT scan mastoid membutuhkan tingkat ketajaman yang optimal. Dengan penggunaan filter bone sharp maka gambaran seperti tulang, soft tissue dan jaringan - jaringan lain dapat dibedakan dengan jelas pada layar monitor, filter untuk resolusi tinggi yaitu yang mampu memperjelas tepian atau ujung - ujung gambar akan menghasilkan image yang lebih baik.

\section{Kesimpulan}

Dari pembahasan penelitian diatas maka dapat ditarik kesimpulan bahwa terdapat perbedaan kualitas citra CT scan mastoid pada penggunaan variasi 3 filter rekonstruksi pemeriksaan CT scan amstoid. Serta disarankan dalam rekonstruksi pemeriksaan CT Scan Mastoid hendaknya menggunakan filter bone sharp dalam mendiagnosa klinis mastoiditis untuk mengevaluasi struktur tulang dan mastoid air cell, serta menggunakan filter standart untuk mengevaluasi jaringan sekitar tulang mastoid.

\section{Daftar Pustaka}

Alper, C. M., Luntz, M., Takahashi, H., Ghadiali, S. N., Swarts, J. D., Teixeira, M. S., Csákányi, Z., Yehudai, N., Kania, R., \& Poe, D. S. (2017). Panel 2: Anatomy (Eustachian Tube, Middle Ear, and Mastoid-Anatomy, Physiology, Pathophysiology, and Pathogenesis). Otolaryngology - Head and Neck Surgery (United States). https://doi.org/10.1177/01945998166479 59

Cheng, T., Chen, D., Yu, B., \& Niu, H. (2017). Reconstruction of superresolution STORM images using compressed sensing based on lowresolution raw images and interpolation. Biomedical Optics Express. https://doi.org/10.1364/boe.8.002445

Darmini, Ari Setiyono, P., Rochmayanti, D., Nino Kurniawan, A., \& Nugroho Setiawan, A. (2020). The Optimization of Mastoid CT Image Using Windows and Kernel Reconstructions. Journal of Physics: Conference Series. https://doi.org/10.1088/17426596/1471/1/012015

Heilbrun, M. E., Salzman, K. L., Glastonbury, C. M., Harnsberger, H. R., Kennedy, R. J., \& Shelton, C. (2003). External auditory canal cholesteatoma: Clinical and imaging spectrum. American 
Journal of Neuroradiology.

Juliano, A., Ginat, D., \& Moonis, G. (2013). Imaging Review of the Temporal Bone: Part I. Anatomy and Inflammatory and Neoplastic Processes. Radiology.

Louis, R. G., Loukas, M., Wartmann, C. T., Tubbs, R. S., Apaydin, N., Gupta, A. A., Spentzouris, G., \& Ysique, J. R. (2009). Clinical anatomy of the mastoid and occipital emissary veins in a large series. Surgical and Radiologic Anatomy. https://doi.org/10.1007/s00276-0080423-5

Petaros, A., Sholts, S. B., Slaus, M., Bosnar, A., \& Wärmländer, S. K. T. S. (2015). Evaluating sexual dimorphism in the human mastoid process: A viewpoint on the methodology. In Clinical Anatomy. https://doi.org/10.1002/ca.22545

Reiser, M. F., Hricak, H., Knauth, M., Thomsen, H. S., \& Webb, J. A. W. (2014). Contrast media. Safety Issues and ESUR. In Medical Radiology Diagnostic Imaging (Third). Springer.

Romans, L. E. (2018). Computed tomography for technologists: A comprehensive text, second edition (First Edit). Wolters Kluwer Health.

Schaefer-Prokop, C., Prokop, M., Fleischmann, D., \& Herold, C. (2001). High-resolution CT of diffuse interstitial lung disease: Key findings in common disorders. European Radiology. https://doi.org/10.1007/s003300000648

Seeram, E. (2016). COMPUTED TOMOGRAPHY Physical Principles, Clinical Applications, and Quality Control FOURTH EDITION. http://evolve.elsevier.com/Seeram/YOU' VEJUSTPURCHASED

Swarts, J. D., Alper, C. M., Luntz, M., Bluestone, C. D., Doyle, W. J., Ghadiali, S. N., Poe, D. S., Takahashi, H., \& Tideholm, B. (2013). Panel 2: Eustachian tube, middle ear, and mastoid-anatomy, physiology, pathophysiology, and pathogenesis. Otolaryngology - Head and Neck Surgery (United States). https://doi.org/10.1177/01945998124726 31

Swartz, J. D. (2001). Temporal bone trauma. Seminars in Ultrasound CT and MRI.
https://doi.org/10.1016/S08872171(01)90008-3

The Essential Physics of the Medical Imaging, 3rd edJerrold T. Bushberg, J. Anthony Seibert, Edwin M. Leidholdt, Jr, and John M. Boone Philadelphia, Pa: Lippincott Williams \& Wilkins, 2012. ISBN: 978-0-7817-8057-5. Hardcover, \$199.99; pp 1048. (2015). Radiology. https://doi.org/10.1148/radiol.14144045 